\title{
MULTI-AXIAL MECHANICAL STIMULATION OF TISSUE ENGINEERED CARTILAGE: REVIEW
}

\author{
Stephen D. Waldman ${ }^{1,2}$, David C. Couto ${ }^{2}$, Marc D. Grynpas ${ }^{2,3}$, Robert M. Pilliar ${ }^{2}$ and Rita A. Kandel ${ }^{2,3}$ \\ ${ }^{1}$ Department of Mechanical and Materials Engineering, Department of Chemical Engineering, Queen's University, \\ Kingston, Ontario, Canada \\ ${ }^{2}$ CIHR-Bioengineering of Skeletal Tissues Team, Mount Sinai Hospital and University of Toronto, Toronto, Ontario, \\ Canada \\ ${ }^{3}$ Samuel Lunenfeld Research Institute, Mount Sinai Hospital, Toronto, Ontario, Canada.
}

\begin{abstract}
The development of tissue engineered cartilage is a promising new approach for the repair of damaged or diseased tissue. Since it has proven difficult to generate cartilaginous tissue with properties similar to that of native articular cartilage, several studies have used mechanical stimuli as a means to improve the quantity and quality of the developed tissue. In this study, we have investigated the effect of multi-axial loading applied during in vitro tissue formation to better reflect the physiological forces that chondrocytes are subjected to in vivo. Dynamic combined compression-shear stimulation (5\% compression and 5\% shear strain amplitudes) increased both collagen and proteoglycan synthesis ( $76 \pm 8 \%$ and $73 \pm 5 \%$, respectively) over the static (unstimulated) controls. When this multiaxial loading condition was applied to the chondrocyte cultures over a four week period, there were significant improvements in both extracellular matrix (ECM) accumulation and the mechanical properties of the in vitroformed tissue (3-fold increase in compressive modulus and 1.75 -fold increase in shear modulus). Stimulated tissues were also significantly thinner than the static controls (19\% reduction) suggesting that there was a degree of ECM consolidation as a result of long-term multi-axial loading. This study demonstrated that stimulation by multi-axial forces can improve the quality of the in vitro-formed tissue, but additional studies are required to further optimize the conditions to favour improved biochemical and mechanical properties of the developed tissue.
\end{abstract}

Key Words: Tissue engineering, articular cartilage, calcium polyphosphate substrates, chondrocytes, compression, shear, mechanical stimulation.

\footnotetext{
Address for correspondence:

Stephen D. Waldman

Department Mechanical and Materials Engineering

Department of Chemical Engineering

McLaughlin Hall, Room 205, Queen's University

Kingston, Ontario, Canada K7L 3N6

Telephone Number: (613) 533-2896

FAX Number: (613) 533-6489

Email: waldman@me.queensu.ca
}

\section{Introduction}

Resurfacing damaged joint cartilage with tissue formed in vitro is a promising new approach for articular cartilage repair. Isolated cartilage cells (chondrocytes) grown in three-dimensional culture are capable of synthesizing a cartilaginous extracellular matrix (ECM) which is similar to that of the native tissue (Buschmann et al., 1992; Buschmann et al.,1995; Vunjak-Novakovic et al., 1999; Waldman et al., 2002). Although much progress has been made in refining this approach, it still has proven difficult to accumulate enough ECM to produce a tissue with properties that mimic native articular cartilage (Buschmann et al., 1992; Buschmann et al., 1995; Duda et al., 2000; Jin et al., 2001; Waldman et al., 2002).

As a potential strategy to produce functional cartilaginous tissue in vitro, several studies have investigated the effect of mechanical stimuli applied during in vitro tissue formation. Based on the premise that mechanical factors play an important role in the development and maintenance of healthy cartilage in vivo (Kiviranta et al., 1988; Beaupre et al., 2000; Grodzinsky et al., 2000), numerous investigators have shown that both dynamic compressive (Buschmann et al., 1995; Lee and Bader, 1997; Lee et al., 1998; Lee et al., 2000; Waldman et al., 2004) and shear (Waldman et al., 2003a) loading of chondrocytes in 3D culture stimulate the synthesis of cartilaginous ECM macromolecules. When the stimulus is applied intermittently over a long duration (i.e. several weeks) the cells accumulate greater amounts of ECM which also results in the improved mechanical performance of the in vitro-formed tissue (Mauck et al., 2000; Mauck et al., 2003; Chowdhury et al., 2003; Waldman et al., 2003a; Waldman et al., 2003b; Waldman et al., 2004). Although the application of these relatively simple loading conditions has resulted in beneficial effects, articular cartilage in vivo is subjected to complex loading consisting of a combination of both compressive and shearing forces under normal physiological conditions (Mankin et al., 1994). This pattern of loading not only arises from the combination of compressive and shearing forces directly applied to the tissue but also from the nonhomogenous structure of its ECM (Mankin et al., 1994) which can create a multi-axial stress-state within the tissue. Some studies have investigated the effect of complex loading applied to the engineered through the use of a rotating or rolling ball that is compressed against the tissue surface to simulate physiological loading (Wimmer et al., 2004; Grad et al., 2005; Grad et al., 2006; Stoddart et al., 
2006). Although in these experiments multi-axial loads were applied to the tissue, they were not well-defined as the applied strains (or stresses) would be highly dependent on the experimental setup (ball diameter, surface roughness, lubricant choice, etc.). Alternatively, a device capable of applying well-defined multi-axial strains (or stresses) to tissue samples (e.g., Frank et al., 2000; Heiner and Martin, 2004; Waldman et al., 2003a) could be utilized to more thoroughly investigate the effect of multi-axial loading on the engineered tissue. Thus, the purpose of this study was to investigate whether dynamic combined compression-shearing strains applied to chondrocytes maintained in $3 \mathrm{D}$ culture would increase ECM accumulation and improve the mechanical performance of the in vitro-formed tissue.

\section{Materials and Methods}

\section{Formation of cartilage in vitro}

To generate cartilaginous tissue in vitro, chondrocytes were isolated from the full-thickness of bovine metacarpalcarpal articular cartilage (6-9 months old) by sequential enzymatic digestion (collagenase followed by protease), as described previously (Boyle et al., 1995; Waldman et al., 2002). Cartilage from 2 to 3 animals was combined to obtain sufficient cells to perform an experiment. Isolated cells were re-suspended in Ham's F12 supplemented with $25 \mathrm{mM}$ HEPES and 5\% foetal bovine serum (Sigma Chemical Co., St. Louis, Mo). Chondrocytes were seeded on the surface of porous calcium polyphosphate (CPP) substrates (4 mm diameter x $6 \mathrm{~mm}$ long) fabricated as previously described (Filiaggi et al., 1998; Pilliar et al., $2001)$ at a density of 160,000 cells $/ \mathrm{mm}^{2}\left(\sim 2 \times 10^{6}\right.$ cells/ construct). CPP cylinders had been encased in Tygon ${ }^{\mathrm{TM}}$ tubing (Thermoplastics Processor Inc., San Jose, CA) to prevent chondrocytes from spilling over the edge of the substrate and sterilized by $\gamma$-irradiation (3.5 Mrad) prior to cell seeding (Waldman et al., 2002). The cultures were grown in an incubator maintained at $37^{\circ} \mathrm{C}$ and $95 \%$ relative humidity supplemented with $5 \% \mathrm{CO}_{2}$. The serum concentration was increased to $20 \%$ at day 5 and on day 7 , $100 \mu \mathrm{g} / \mathrm{mL}$ ascorbic acid was added to the medium. The medium (2 mL per sample) was changed every 2-3 days and fresh ascorbic acid was added with each change. Cultures were maintained under static, free swelling conditions for four weeks to allow for the formation of tissue, before the application of mechanical loading.

\section{Combined compression-shear stimulation}

After four weeks of static culture, the Tygon ${ }^{\mathrm{TM}}$ tubing was removed and the height of the tissue formed above the surface of the CPP substrate was determined using a laser displacement transducer (Newport Electronics Inc., Santa Ana, CA). Intermittent mechanical stimulation of the cartilaginous tissue-CPP substrate constructs (four at a time) was then performed using a two-axis (compression and linear shear) Mach-1 ${ }^{\mathrm{TM}}$ mechanical tester (Biosyntech, Laval, PQ) with custom designed titanium alloy (Ti 6Al $4 \mathrm{~V})$ platens in conjunction with standard 24-well tissue culture plates (BD Falcon, San Jose, CA) (Waldman et

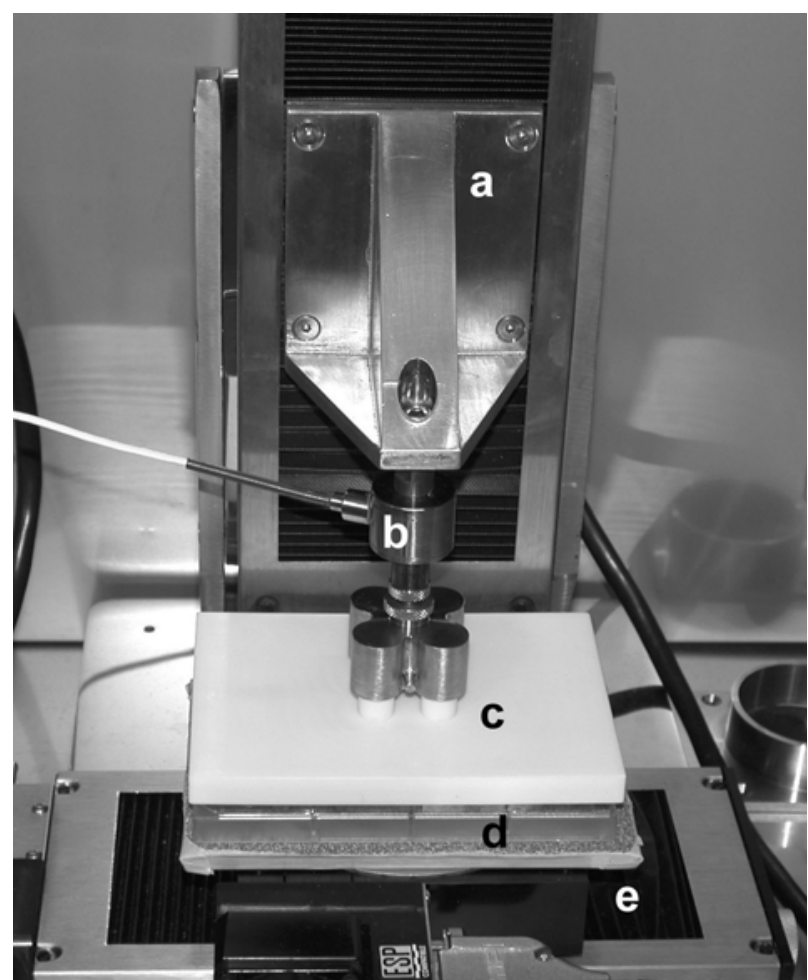

Figure 1. Photograph of the dual-axis (compression and translational shear) Mach-1 ${ }^{\mathrm{TM}}$ mechanical tester housed in a standard incubator. (a) compression actuator, (b) compression load cell, (c) custom designed culture plate top with titanium alloy (Ti6Al4V) loading platens, (d) standard 24-well tissue culture plate and (e) translational shear actuator (reprinted with permission (Waldman et al., 2003a)).

al., 2003a) (Fig. 1). Before the application of dynamic mechanical loading, tissues were subjected to an average preload of $0.5 \mathrm{~g} /$ construct to provide adequate gripping forces and prevent slippage of the sample during stimulation. Tissues were subjected to unconfined combined, in-phase compression-linear shear loading at different strain amplitudes based on prior studies which investigated the effect of either dynamic compressive (Waldman et al. 2004) or shear (Waldman et al., 2003a) loading. From the results of these studies, the following four loading conditions were investigated: (i) $2 \%$ compression- $2 \%$ shear, (ii) 5\% compression-2\% shear, (iii) $2 \%$ compression- $5 \%$ shear and (iv) $5 \%$ compression- $5 \%$ shear. For all conditions, dynamic mechanical loading was conducted for 400 cycles per day at a frequency of $0.5 \mathrm{~Hz}$. Tissues were stimulated every other day for one week (three times) aseptically in culture media at $37^{\circ} \mathrm{C}$. The controls were maintained under the same culture conditions but did not receive any stimulation.

Once the optimal conditions were identified (by assessing collagen and proteoglycan synthesis), cultures were established to examine the effects of "long-term" multi-axial stimulation applied over the final four weeks of an eight week (total duration) culture period. Controls consisted of cultures that did not receive any stimulation (static culture for the entire eight weeks of culture). The thickness of the tissue was determined each week, as described above, in order to adjust the displacement 
amplitudes to compensate for the growth of the tissue during the culture period.

\section{Proteoglycan and collagen synthesis}

For the short-term studies, the tissues (stimulated and unstimulated controls) after one week of intermittent mechanical stimulation were incubated in the presence of both $\left[{ }^{35} \mathrm{~S}_{\mathrm{SO}_{4}}(6 \mu \mathrm{Ci} /\right.$ construct $)$ to label proteoglycans and $\left[{ }^{3} \mathrm{H}\right]$ proline $(5 \mu \mathrm{Ci} /$ construct $)$ to label collagen for 24 hours. Although proline can be incorporated into different types of proteins, collagen is the predominant proline-containing protein synthesized by chondrocytes ( $\sim 90 \%$ of proline becomes incorporated into collagen, as shown in previous studies) (Peterkofsky and Diegelmann, 1971; Sun and Kandel, 1999). Unincorporated isotope was removed from the tissue by washing the samples three-times in phosphatebuffered saline. The tissues were digested by papain (40 $\mu \mathrm{g} / \mathrm{ml}$ in $20 \mathrm{mM}$ ammonium acetate, $1 \mathrm{mM}$ EDTA, and 2 mM DTT) for 48 hours at $65^{\circ} \mathrm{C}$. Proteoglycan and collagen synthesis was estimated by quantifying radioisotope incorporation from aliquots of the papain digest using a $\beta$-liquid scintillation counter (Beckman LS6000TA, Beckman Instruments, Mississauga, Ontario). Matrix synthesis was calculated relative to the DNA content of the tissue (see below) and expressed as a percentage of the unstimulated controls.

\section{Mechanical properties}

After four weeks of mechanical stimulation under the optimal conditions (total of eight weeks of culture), the thickness and diameter of the tissue (stimulated and unstimulated controls) were measured using a digital micrometer (Mitutoyo American Corporation, Aurora, IL). Equilibrium mechanical properties of the cartilaginous tissue-CPP substrate constructs in both compression and shear were then assessed using a Mach-1 $1^{\mathrm{TM}}$ mechanical tester (Biosyntech, Laval, PQ) and a LabVIEW 5.0 control/ data acquisition interface (National Instruments, Austin, TX).

Samples were first preloaded to $1 \mathrm{~g}$, which was defined as the zero strain state. Samples were then subjected to sequential step unconfined compressions of $2 \%$ strain to a maximum of $20 \%$ strain. At each step, the resulting force decay was recorded until equilibrium (defined as a change in force less than $0.2 \mathrm{~g} / \mathrm{min}$ ) was reached. Tissues were then unloaded and allowed to relax for a period of 30 minutes before determining the mechanical properties in shear. Samples were preloaded again (to $1 \mathrm{~g}$ ) and then subjected to sequential step simple linear shearing strains of $1 \%$ to a maximum of $10 \%$ shear strain (allowing equilibrium to be achieved at each step). For both compression and shear, the equilibrium stress (equilibrium force normalized by the cross-sectional area of the sample) was plotted as a function of the applied strain. The equilibrium modulus was determined from a second-order numerical derivative of the equilibrium stress-strain curve and determined at a specific strain value: $20 \%$ compressive strain and $0 \%$ shear strain. All mechanical testing was conducted at $37^{\circ} \mathrm{C}$ with the tissues completed submersed in culture media.

\section{Physical and biochemical properties}

After mechanical testing, the in vitro-formed cartilaginous tissue was removed from the surface of the CPP substrate using a scalpel blade (No. 11) and weighed (AT-250 Balance, Mettler Instrument Corporation, Heightstown, NJ). Tissues were lyophilyzed overnight and the dry weight of the tissue determined. The water content of the tissue was defined as the percentage difference between the wet and dry weights.

Lyophilyzed tissues were then digested by papain, as described above, and stored at $-20^{\circ} \mathrm{C}$ until analysis. Aliquots of the digest were assayed separately for the proteoglycan, collagen and DNA contents. Briefly, the proteoglycan content was estimated by quantifying the amount of sulphated glycosaminoglycans using the dimethylmethylene blue dye binding assay (Goldberg and Kolibas, 1990). Collagen content was estimated from the determination of the hydroxyproline content. Aliquots of the papain digest were hydrolyzed in $6 \mathrm{~N} \mathrm{HCl}$ at $110^{\circ} \mathrm{C}$ for 18 hours and the hydroxyproline content of the hydrolyzate was then determined using chloramine-T/ Ehrlich's reagent assay (Woessner, 1976). The DNA content was also determined from aliquots of the papain digest using the Hoechst dye 33258 assay (Kim et al., 1988).

\section{Statistics}

Each experiment was done in triplicate and the results pooled yielding a minimum sample size of $n=6$ per group. All results were expressed as the mean \pm standard error of the mean (SEM) and analyzed using statistical software (SPSS v12.0, Chicago, IL). Prior to conducting parametric statistical analyses, both normality and equal variance assumption were confirmed. Collagen and proteoglycan synthesis results after one week of stimulation were analyzed using a one-way ANOVA with pair-wise comparisons between groups conducted using the Fisher's LSD post-hoc test. Physical, biochemical and mechanical characterization results from the "long-term" stimulation experiments were compared between the stimulated and control (unstimulated) tissues using unpaired $t$-tests. Significance was assigned to $p$-values less than 0.05 .

\section{Results}

\section{Effect of multi-axial stimulation on extracellular matrix synthesis}

Chondrocytes cultures were maintained for a period of four weeks and then subjected to different degrees of combined compression-shear loading every other day for one week (total of three periods of stimulation). This was done to identify the parameters that would maximally stimulate ECM synthesis. Although all loading conditions investigated resulted in significantly different ECM synthesis compared to the unstimulated controls $(p<0.01)$, differential effects were observed depending on the amount of compressive stimulation to which the tissues were subjected (Fig. 2). The application of low amplitude compressive strains $(2 \%)$ increased ECM synthesis $(29 \pm$ 


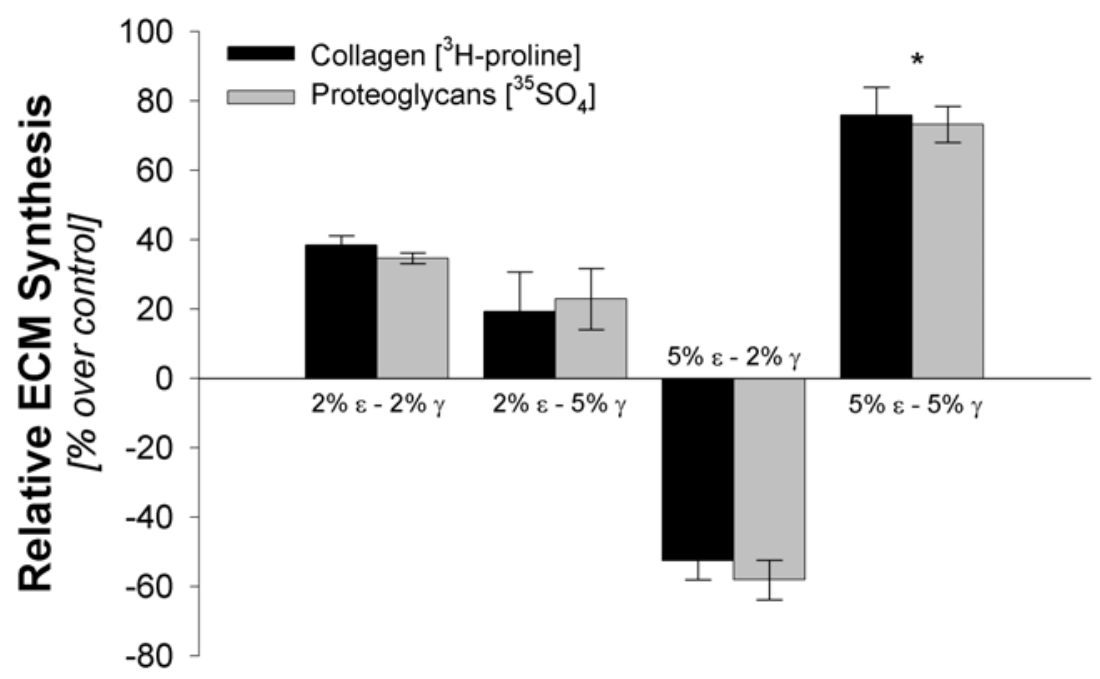

Figure 2. Changes in collagen (black bars) and proteoglycan (grey bars) synthesis expressed relative to the unstimulated controls following one week of combined compression-shear stimulation. The applied compressive $(\varepsilon)$ and shearing $(\gamma)$ strain amplitudes for each loading group are indicated. Two separate experiments were performed, results pooled and expressed as the mean \pm standard error of the mean ( $n=6$ for all groups). The asterisk $(*)$ denotes the condition used in the "long-term" experiments.

$6 \%$ and $29 \pm 5 \%$ above control for collagen and proteoglycans, respectively) independent of the amount of shearing strain applied (either $2 \%$ or $5 \%, p=0.3$ ). At higher compressive strain amplitudes $(5 \%)$, the amount of shearing strain applied dramatically influenced the change in ECM synthesis with low shearing strains (2\%) inhibiting ECM synthesis whereas high shearing strains (5\%) increasing ECM synthesis. This later condition $(5 \%$ compressive strain $-5 \%$ shearing strain) also resulted in the largest increase in ECM synthesis $(76 \pm 8 \%$ and $73 \pm$ $5 \%$ above control for collagen and proteoglycans, respectively) compared to the other loading conditions and was used for the "long-term" stimulation studies.

\section{Effect of long-term multi-axial stimulation on tissue composition and properties}

Combined compressive-shear stimulation applied intermittently over a four-week period (total of eight weeks of culture) significantly affected both the physical and biochemical properties of the tissue (Table 1). Tissues that received long-term multi-axial loading were significantly thinner (by 19\%) than the unstimulated controls without any observed differences in tissue diameter or weight. Long-term stimulated tissues also accumulated significantly more ECM with an observed increase in both collagen (by $\sim 54 \%$ ) and proteoglycans (by $\sim 46 \%$ ). Stimulated tissues also appeared to have a slightly lower DNA content compared to the unstimulated controls; however, this effect was not significant $(p=0.2)$.

Four weeks of combined compression-shear stimulation also significantly improved the mechanical properties of the in vitro-formed tissue as measured in both compression and shear. Tissues cultured in the presence of combined compression-shear stimulation displayed on average a 3-fold increase in compressive modulus and a 1.75 -fold increase in shear modulus compared to the unstimulated controls (Figs. 3 and 4, Table 1).

\section{Discussion}

In this study, we have investigated the effect of "longterm" combined compression-shear cyclic loading on the composition and mechanical properties of cartilaginous tissue formed in vitro. Previous studies have shown that the application of mechanical forces can stimulate extracellular matrix (ECM) synthesis by chondrocytes in vitro (e.g., Buschmann et al., 1995; Lee and Bader, 1997; Lee et al., 2000; Waldman et al., 2003a; Waldman et al., 2003b; Waldman et al., 2004). Although it is well known that chondrocytes are subjected to multi-axial forces in vivo (Mankin et al., 1994), the majority of these studies have only examined the effect of cyclic uniaxial loading (compression or shear). Some studies have investigated the effect of multi-directional simulated physiological loading (Wimmer et al., 2004; Grad et al., 2005; Grad et al., 2006; Stoddart et al., 2006); however, the applied strains (or stresses) are not easily quantifiable so it is difficult to correlate precisely the extent of multi-axial loading with changes in the growth of tissue engineered cartilage. However, there has been one report describing how equal-magnitude axial and transverse compression alters ECM synthesis but this study was done using cartilage explants (Heiner and Martin, 2004), which is different from in vitro-formed cartilage.

In the present study, dynamic combined compressionshear loading of the in vitro-formed tissue resulted in differential effects on the synthesis of ECM depending on the relative magnitudes of the applied compressive and shearing strains. The application of low amplitude compressive strains, independent of the amount of applied shear, resulted in increased ECM synthesis. However, at higher compressive strains, the magnitude of the applied shearing strains significantly influenced ECM synthesis with low shearing strains inhibiting synthesis and high shearing strains stimulating ECM synthesis. Although it 


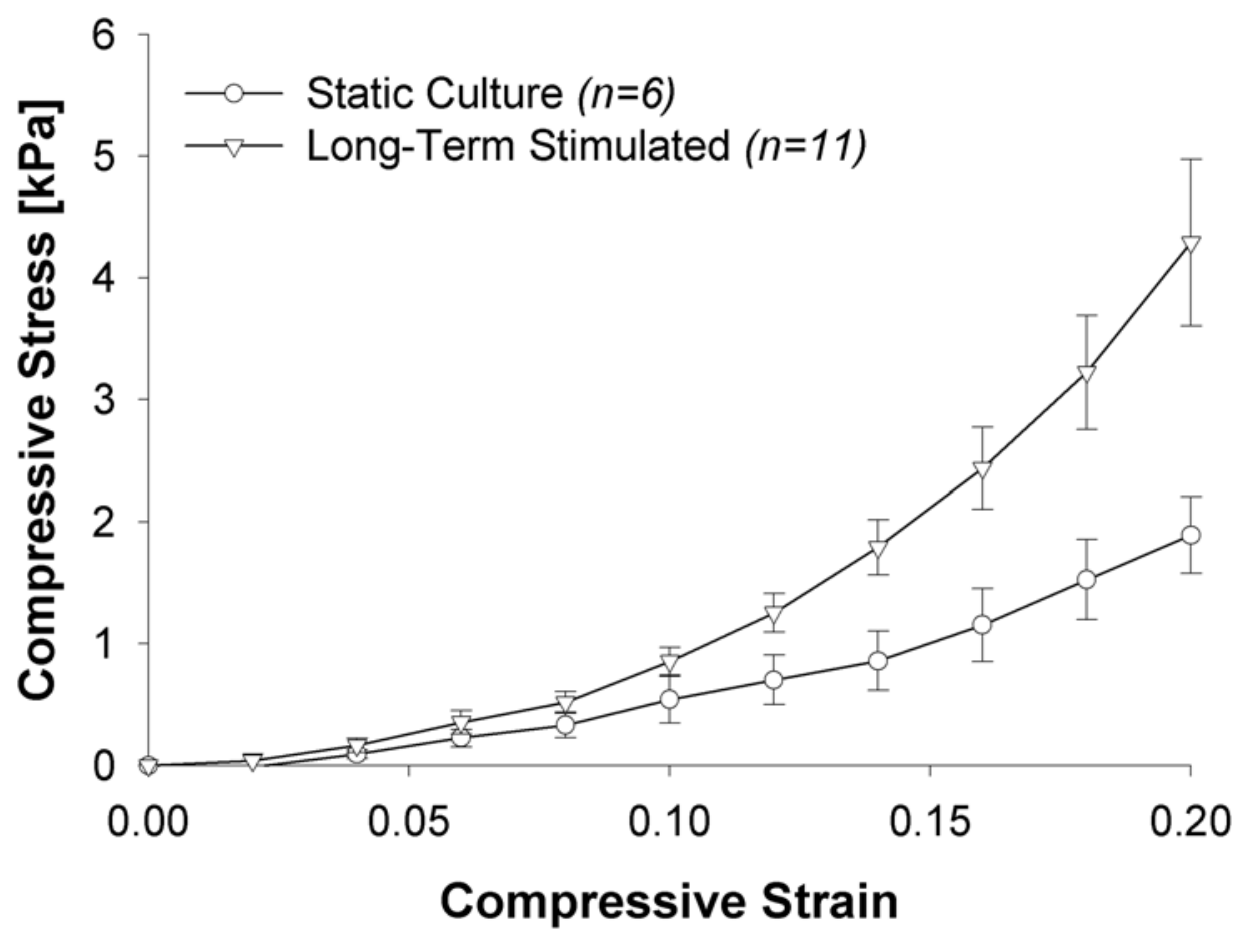

Figure 3. The equilibrium compressive stress-strain behaviour of the tissues cultured in the presence or absence of "long-term" combined compression-shear stimulation. Equilibrium mechanical testing was conducted between 0$20 \%$ compressive strain at $2 \%$ compressive strain increments. Three separate experiments were performed, results pooled and expressed as the mean \pm standard error of the mean $(\mathrm{n}=$ total number of tissues analyzed $)$.

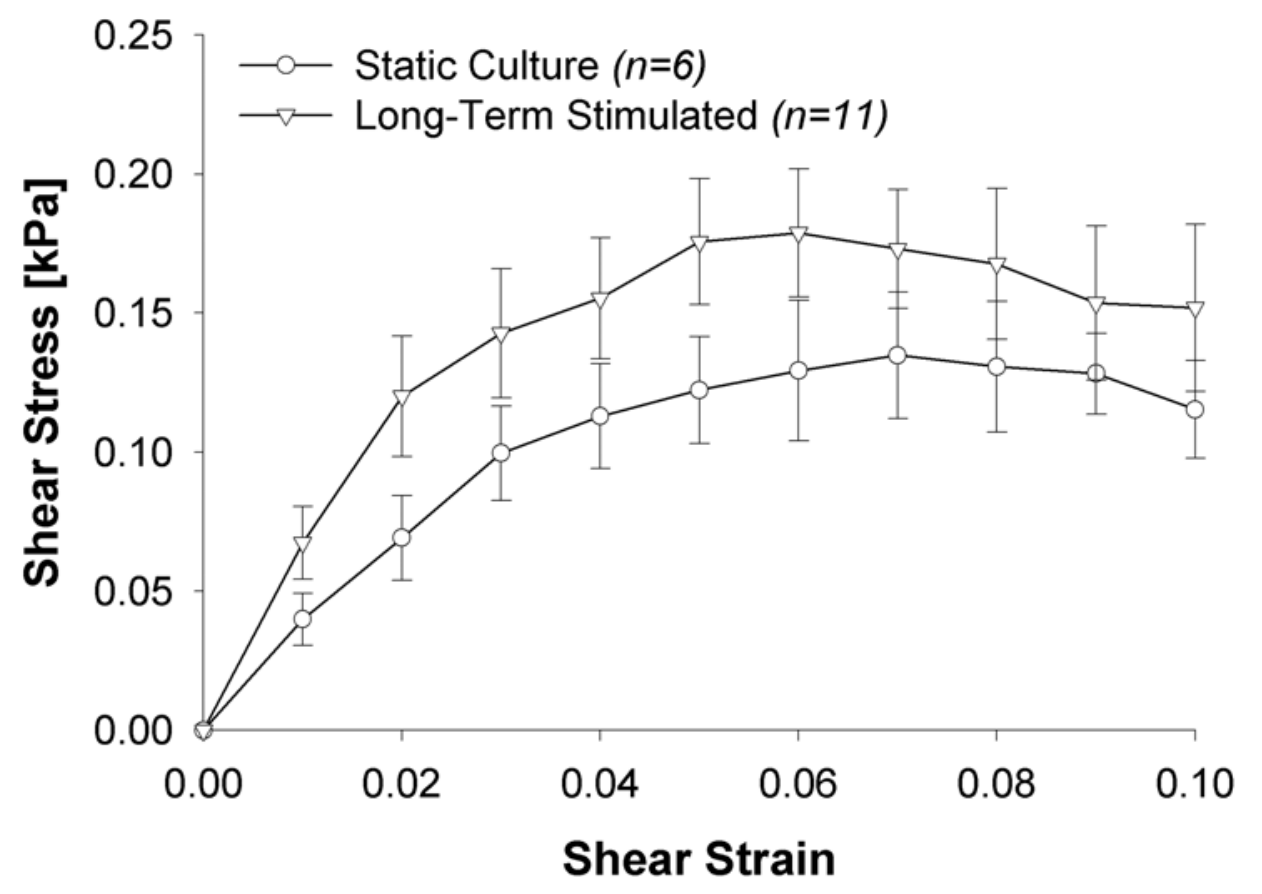

Figure 4. The equilibrium shear stress-strain behaviour of the tissues cultured in the presence or absence of "longterm" combined compression-shear stimulation. Equilibrium mechanical testing was conducted between 0-10\% shearing strain at $1 \%$ shear strain increments. Three separate experiments were performed, results pooled and expressed as the mean \pm standard error of the mean $(n=$ total number of tissues analyzed). 
Table 1: Properties of in vitro-formed tissues

\begin{tabular}{|c|c|c|}
\hline & $\begin{array}{l}\text { Static Culture } \\
(\mathrm{n}=6)\end{array}$ & $\begin{array}{l}\text { Compression-Shear Stimulated } \\
(\mathrm{n}=11)\end{array}$ \\
\hline Thickness [mm] & $1.6 \pm 0.2^{\mathrm{a}}$ & $1.3 \pm 0.2^{\mathrm{a}}$ \\
\hline Diameter $[\mathrm{mm}]$ & $5.2 \pm 0.1$ & $5.0 \pm 0.1$ \\
\hline Dry Weight [mg] & $2.2 \pm 0.5$ & $2.2 \pm 0.2$ \\
\hline Water Content $[\%]$ & $89.1 \pm 0.9$ & $87.8 \pm 0.6$ \\
\hline DNA $[\mu \mathrm{g}]$ & $11 \pm 4$ & $8 \pm 3$ \\
\hline Proteoglycans/DNA $[\mu \mathrm{g} / \mu \mathrm{g}]$ & $46 \pm 4^{\mathrm{a}}$ & $71 \pm 5^{\mathrm{a}}$ \\
\hline Collagen/DNA $[\mu \mathrm{g} / \mu \mathrm{g}]$ & $48 \pm 5^{b}$ & $70 \pm 7^{b}$ \\
\hline Compressive Modulus $[\mathrm{kPa}] \dagger$ & $18 \pm 6^{\mathrm{a}}$ & $53 \pm 11^{\mathrm{a}}$ \\
\hline Shear Modulus $[\mathrm{kPa}] \$$ & $4 \pm 1^{b}$ & $7 \pm 1^{b}$ \\
\hline
\end{tabular}

a significant difference between stimulated and static control $(\mathrm{p}<0.01)$

b significant difference between stimulated and static control $(p<0.05)$

$\uparrow$ determined from equilibrium testing at $20 \%$ compressive strain

$\$$ determined from equilibrium testing at $0 \%$ shearing strain

The physical, biochemical and mechanical properties of the in vitro-formed cartilaginous tissues cultured in the presence or absence of "long-term" (4 weeks) combined compression-shear stimulation is presented. Three separate experiments were performed, the results were pooled and expressed as the mean \pm standard error of the mean ( $n=$ the total number of tissues analyzed).

is not exactly known why this particular combination of multi-axial strains led to an inhibition of ECM synthesis, one potential explanation is the local variation of compressive strains created in the tissue during multi-axial deformation. During unconfined uniaxial compression, there is a tendency for the tissue to expand laterally (Poisson effect) and the sample can take on a barrel-like shape (referred to as "barrelling") (Lee and Kuhn, 1973). Previous studies have shown that ECM synthesis induced by unconfined dynamic compression appears to correlate with this effect as more synthesis was observed at the periphery of the sample where the "barrelling effect" predominates (Buschmann et al., 1999). However, when small shearing strains are applied in conjunction with unconfined compression, the applied shear can restrict the lateral expansion of the sample. Interestingly, this effect has been used as a strategy to limit barrelling distortion during compression in material test samples (Rittel et al., 2002). This combination of loading (combined compression-shear) can resemble a confined-compression state in which there are no tensile strains occurring outof-plane. Previous studies on cartilage explants exposed to confined-compression have typically resulted in the inhibition of ECM synthesis (Heiner and Martin, 2004) potentially explaining the effect observed in the present study. It should be mentioned that this effect likely would diminish when the applied shearing strains are large and elicit considerable shearing distortion within the tissue. In the present study, when equal-magnitude compressionshear strains were applied, the largest increase in ECM synthesis was observed.

Interestingly, when the in vitro-formed cartilaginous tissues were subjected to stimulatory multi-axial loading conditions ( $5 \%$ compression $-5 \%$ shear) intermittently over a period of four weeks, cells in the stimulated tissues appeared to accumulate more ECM ( $46 \%$ more collagen and $54 \%$ more proteoglycans) compared to the unstimulated controls. This increase in ECM accumulation likely explains the improved mechanical properties as measured in both compression (3-fold increase in modulus) and shear (1.75-fold increase in modulus) of the stimulated tissues compared to those formed in absence of multi-axial loading. Along with the observed increase in tissue mechanical properties, there was also a reduction of tissue thickness (by 19\%) without an associated change in diameter after long-term multi-axial mechanical stimulation. This suggests that the ECM of the stimulated tissues also underwent a degree of consolidation (or compaction) as a result of mechanical stimulation thereby leading to improved mechanical properties of the stimulated tissues. Although this effect has not typically been described during the mechanical stimulation of tissue engineered cartilage, matrix consolidation has been commonly used to explain the observed changes in mechanical behaviour of cartilage explants subjected to dynamic loading (Wong et al., 1999; Wong and Carter, 2003; Alhadlaq and Xia, 2004; King et al., 2005). In conjunction with these changes was an associated decline in the total DNA content of the stimulated tissues; however, this decrease was not statistically significant. Although the exact reason for the reduction DNA content is not known, the most likely explanations are either an increase in cell death or inhibition of proliferation. This speculation is supported by a recent study which investigated the effects of mechanical stimulation on cell viability of chondrocytes maintained in $3 \mathrm{D}$ culture. Upon the application of mechanical stimuli, there was a decline in cell viability as well as an inhibition of the cell cycle (Huselstein et al., 2006). 
Upon comparison to our previous studies (Waldman et al., 2003a; Waldman et al., 2003b; Waldman et al., 2004) on the effects of dynamic compressive and shearing forces on the growth of tissue engineered cartilage, some interesting conclusions may be drawn. Cyclic mechanical loading, independent of the types of applied forces (compressive, shear or combined modes), typically elicits increased ECM synthesis. However, when the stimulus is applied over the long-term (i.e. duration of weeks) the resultant effect on the engineered tissue appears to be dependent on the mode of force application. Compressive loading generally lead to an increase in tissue mass without much change in the proportion of accumulated ECM constituents (constant collagen-to-proteoglycan ratio) leading to improvement in the mechanical properties of the developed tissue ( $\sim$-fold change in modulus). While there is generally not an overall increase in tissue mass after the long-term application of cyclic shearing forces, the proportion of cartilaginous ECM constituents can be altered (increase in collagen-to-proteoglycan ratio) with some degree of matrix consolidation. Together these two effects can lead to substantially improved mechanical performance ( $\sim 6$-fold change in modulus). However, with combined cyclic compression-shear forces the dominant effect appears to be matrix consolidation without a change in tissue mass resulting in a modest change in tissue mechanical behaviour ( $\sim 2$-fold change in modulus $)$. This suggests that even though articular cartilage is subjected to both compressive and shearing forces under normal physiological conditions, greater effects on cartilaginous tissue growth and resultant mechanical properties appear to be achieved through the application of cyclic uniaxial loading (compression or shear only).

In this study, we investigated the effect of multi-axial mechanical stimulation on the growth and properties of cartilaginous tissue formed in vitro. Combined compression-shear stimulation applied over a period of four weeks improved ECM accumulation and the mechanical properties of the tissue in both compression and shear. Although these effects were significant, greater responses to uniaxial loading (compression or shear) have been observed in prior studies (Mauck et al., 2000; Waldman et al., 2003a; Waldman et al., 2003b; Waldman et al., 2004). Thus, additional studies are required to further examine other conditions to determine if it is possible to further enhance the biochemical and mechanical properties of the in vitro-formed tissue.

\section{Acknowledgements}

Supported by the Canadian Arthritis Network (CAN), Canadian Institutes of Health Research (CIHR) and the National Science and Engineering Research Council of Canada (NSERC). The authors would like to acknowledge Dr. Jason Hong (Institute of Biomaterials and Biomedical Engineering, University of Toronto) who fabricated the calcium polyphosphate substrates used in this study. We would also like to thank Ryding-Regency Meat Packers and Harry Bojarski for providing the animal tissues.

\section{References}

Alhadlaq HA, Xia Y (2004) The structural adaptations in compressed articular cartilage by microscopic MRI (microMRI) T(2) anisotropy. Osteoarthritis Cartilage 12: 887-894.

Beaupre GS, Stevens SS, Carter DR (2000) Mechanobiology in the development, maintenance, and degeneration of articular cartilage. J Rehabil Res Dev 37: 145-151.

Boyle J, Luan B, Cruz TF, Kandel RA (1995) Characterization of proteoglycan accumulation during formation of cartilagenous tissue in vitro. Osteoarthritis Cartilage 3: 117-125.

Buschmann MD, Gluzband YA, Grodzinsky AJ, Kimura JH, Hunziker EG (1992) Chondrocytes in agarose culture synthesize a mechanically functional extracellular matrix. J Orthop Res 10: 754-758.

Buschmann MD, Gluzband YA, Grodzinsky AJ, Hunziker EG (1995) Mechanical compression modulates matrix biosynthesis in chondrocyte/agarose culture. J Cell Sci 108: 1497-1508.

Buschmann MD, Kim YJ, Wong M, Frank E, Hunziker EB, Grodzinsky AJ (1999) Stimulation of aggrecan synthesis in cartilage explants by cyclic loading is localized to regions of high interstitial fluid flow. Arch Biochem Biophys 366: 1-7.

Chowdhury TT, Bader DL, Shelton JC, Lee DA (2003) Temporal regulation of chondrocyte metabolism in agarose constructs subjected to dynamic compression. Arch Biochem Biophys 417: 105-111.

Duda GN, Haisch A, Endres M, Gebert C, Schroeder D, Hoffmann JE, Sittinger M (2000) Mechanical quality of tissue engineered cartilage: Results after 6 and 12 weeks in vivo. J Biomed Mater Res (Appl Biomater) 53: 673677.

Filiaggi, MJ, Wells, JD, Peel SAF, Pilliar RM, Grynpas MD, Kandel RA (1998) Condensed calcium phosphates for soft tissue and bone repair/regeneration. Bioceramics 11: 341-344.

Frank EH, Jin M, Loening AM, Levenston ME, Grodzinsky AJ (2000) A versatile shear and compression apparatus for mechanical stimulation of tissue culture explants. J Biomech 33: 1523-1527.

Goldberg RL, Kolibas LM (1990) An improved method for determining proteoglycans synthesized by chondrocytes in culture. Connect Tissue Res 24: 265-275.

Grodzinsky AJ, Levenston ML, Jin M, Frank EH (2000) Cartilage tissue remodeling in response to mechanical forces. Annu Rev Biomed Eng 2: 691-713.

Grad S, Lee CR, Gorna K, Gogolewski S, Wimmer MA, Alini M (2005) Surface motion upregulates superficial zone protein and hyaluronan production in chondrocyteseeded three-dimensional scaffolds. Tissue Eng 11: 249256.

Grad S, Lee CR, Wimmer MA, Alini M (2006) Chondrocyte gene expression under applied surface motion. Biorheology 43: 259-269.

Heiner AD, Martin JA (2004) Cartilage responses to a novel triaxial mechanostimulatory culture system. J Biomech 37: 689-695. 
Huselstein C, de Isla N, Kolopp-Sarda MN, Kerdjoudj H, Muller S, Stoltz JF (2006) Influence of mechanical stress on cell viability. Biorheology 43: 371-275.

Jin M, Frank EH, Quinn TM, Hunziker EB, Grodzinsky AJ (2001) Tissue shear deformation stimulates proteoglycan and protein biosynthesis in bovine cartilage explants. Arch Biochem Biophys 395: 41-48.

Kim YJ, Sah RLY, Doong JYH, Grodinsky AJ (1988) Fluorometric assay of DNA in cartilage explants using Hoechst 33258. Anal Biochem 174: 168-176.

King KB, Opel CF, Rempel DM (2005) Cyclical articular joint loading leads to cartilage thinning and osteopontin production in a novel in vivo rabbit model of repetitive finger flexion. Osteoarthritis Cartilage 13: 971978

Kiviranta I, Tammi M, Jurvelin J, Saamanen AM, Helminen HJ (1988) Moderate running exercise augments glycosaminoglycans and thickness of articular cartilage in the knee joint of young beagle dogs. J Orthop Res 6: 188-195.

Lee DA, Bader DL (1997) Compressive strains at physiological frequencies influence the metabolism of chondrocytes seeded in agarose. J Orthop Res 15: 181188.

Lee PW, Kuhn HA (1973) Fracture in cold upset forging - Criterion and model. Metall Trans 4: 969-974.

Lee DA, Noguchi T, Knight MM, O’Donnell L, Bently G, Bader DL (1998) Response of chondrocyte subpopulations within unloaded and loaded agarose. J Orthop Res 16: 727-733.

Lee DA, Noguchi T, Frean SP, Lees P, Bader DL (2000) The influence of mechanical loading on isolated chondrocytes seeded in agarose constructs. Biorheology 37: 149-161.

Mankin HJ, Mow VC, Buckwalter JA, Iannotti JP, Ratcliffe A (1994) Form and function of articular cartilage. Chapter 1. In: Orthopaedic Basic Science (Simon SR, ed.) American Academy of Orthopaedic Surgeons, Columbus, OH. pp 1-44.

Mauck RL, Soltz MA, Wang CC, Wong DD, Chao PH, Valhmu WB, Hung CT, Ateshian GA (2000) Functional tissue engineering of articular cartilage through dynamic loading of chondrocyte-seeded agarose gels. J Biomech Eng 122: 252-260.

Mauck RL, Nicoll SB, Seyhan SL, Ateshian GA, Hung CT (2003) Synergistic action of growth factors and dynamic loading for articular cartilage tissue engineering. Tiss Eng 9: 597-611.

Peterkofsky B, Diegelmann R (1971) Use of a mixture of protease-free collagenases for specific assay of radioactive collagenin the presence of other proteins. Biochemistry 10: 988-994.

Pilliar RM, Filiaggi M, Wells JD, Grynpas MD, Kandel RA (2001) Porous calcium polyphosphate scaffolds for bone substitute application in vitro characterization. Biomaterials 22: 963-972.

Rittel D, Lee S, Ravichandran G (2002) A shearcompression specimen for large strain testing. Exp Mech 42: $58-64$.

Stoddart MJ, Ettinger L, Hauselmann HJ (2006) Enhanced matrix synthesis in de novo, scaffold free cartilage-like tissue subjected to compression and shear. Biotechnol Bioeng 95: 1043-1051.

Sun YL, Kandel RA (1999) Deep zone articular chondrocytes in vitro express genes that show specific changes with mineralization. J Bone Miner Res 14: 19161925.

Vunjak-Novakovic G, Matrin I, Obradovic B, Treppo S, Grodzinsky AJ, Langer R, Freed LE (1999) Bioreactor cultivation conditions modulate the composition and mechanical properties of tissue-engineered cartilage. J Orthop Res 17: 130-138.

Waldman SD, Grynpas MD, Pilliar RM, Kandel RA (2002) Characterization of cartilagenous tissue formed on calcium polyphosphate substrates in vitro. J Biomed Mat Res 62: 323-330.

Waldman SD, Spiteri CG, Grynpas MD, Pilliar RM, Kandel RA (2003a) Long-term intermittent shear deformation improves the quality of cartilaginous tissue formed in vitro. J Orthop Res 21: 590-596.

Waldman SD, Spiteri CG, Grynpas MD, Pilliar RM, Kandel RA (2003b) Effect of biomechanical conditioning on cartilaginous tissue formation in vitro. J Bone Joint Surg 85A: S101-S105.

Waldman SD, Spiteri CG, Grynpas MD, Pilliar RM, Kandel RA (2004) Long-term intermittent compressive stimulation improves the composition and mechanical properties of tissue-engineered cartilage. Tiss Eng 10: 1323-1331.

Wimmer MA, Grad S, Kaup T, Hanni M, Schneider E, Gogolewski S, Alini M (2004) Tribology approach to the engineering and study of articular cartilage. Tissue Eng 10: $1436-1445$.

Woessner JF (1976) Determination of hydroxyproline content in connective tissues. Chapter 23. In: The Methodology of Connective Tissue Research (Hall DA, ed.). Joynson-Bruvvers Ltd, Oxford, pp 227-234.

Wong M, Carter DR (2003) Articular cartilage functional histomorphology and mechanobiology: a research perspective. Bone 33: 1-13.

Wong M, Siegrist M, Cao X (1999) Cyclic compression of articular cartilage explants is associated with progressive consolidation and altered expression pattern of extracellular matrix proteins. Matrix Biol 18: 391-399.

\section{Discussion with Reviewers}

M. Silbermann: Why is the amount of DNA decreased? Could this be due to cell death?

Authors: Although the exact reason for the reduction in DNA content is not known, it was not a statistically significant decrease. The most likely explanation is that it was due to either increased cell death or inhibition of cell proliferation. This speculation is supported by a recent study which investigated the effects of mechanical stimulation on cell viability of chondrocytes maintained in $3 \mathrm{D}$ culture. Upon the application of mechanical stimuli, there was a decline in cell viability as well as an inhibition of the cell cycle (Huselstein et al., 2006, text reference). 
M.J. Stoddart: As the manuscript is describing the construction of tissue engineered tissue, it would benefit greatly by the addition of an image of the produced tissue, ideally a histological image comparing loaded versus unloaded. Could you provide such an image?

Authors: We have presented representative histological sections of the developed tissue in previous studies (Waldman et al., 2002; Waldman et al., 2003). In the present study, however, we did not to perform a rigorous histological analysis of the developed tissues since the changes induced by long-term mechanical stimulation (in both tissue thickness and matrix accumulation) are typically too small to be detected by routine histological methods. It is possible to perform the requested analyses, however, we would require at least an additional threemonth period (as the construct must be embedded in plastic since the CPP substrate is a brittle ceramic material). 